\title{
Nutlet Micromorphological Study on Salvia L. (Lamiaceae) from NE Iran
}

\author{
Seyed Mohammad Mousavi ${ }^{1}$, Azarnoosh Jafari $^{{ }^{*}}$, Shahla Najafi ${ }^{2}$ \\ ${ }^{1}$ Department of Biology, Faculty of sciences, Mashhad Branch, Islamic Azad University, Mashhad, Iran; ${ }^{2}$ Department of Biology, \\ Faculty of Sciences, University of Zabol, Zabol, Iran. \\ Email: *azarnoosh_djafari@mshdiau.ac.ir
}

Received May $12^{\text {th }}, 2013$; revised June $13^{\text {th }}, 2013$; accepted July $1^{\text {st }}, 2013$

Copyright (C) 2013 Seyed Mohammad Mousavi et al. This is an open access article distributed under the Creative Commons Attribution License, which permits unrestricted use, distribution, and reproduction in any medium, provided the original work is properly cited.

\begin{abstract}
In the present research, micromorphological features of 10 Salvia L. nutlets (mericarp) growing in NE Iran were studied by SEM. These species were divided into three and four groups based on the shape and ornamentation of nutlets respectively. The variation in color, size and ornamentation of mericarp helped to identify species.
\end{abstract}

Keywords: Salvia; Iran; Nutlet; Mericarp; Micromorphological Features

\section{Introduction}

Salvia L. belongs to the family Lamiaceae, comprises about 1000 species distributed in temperate and subtropical regions [1]. This genus has 58 species in Iran in which 17 species are endemic [2-4]. Based on Flora Iranica report, 17 Salvia species were distributed in NE Iran [3]. In the present research, micromorphological features of mericarps were assessed for first time in Iran due to high hybridation rate between Salvia species [5] and commercial importance of their nutlets. Although Salvia is the largest genus of Lamiaceae, its mericarp morphology has been poorly reported. There have been a few reports of external micromorphological study on the mericarp of Salvia such as, Nutlet morphology and its taxonomic utility in Salvia from Turkey [6], Morphology, anatomy, palynology and nutlets micromorphology of the rediscovered Turkish endemic Salvia ballsiana and their taxonomic implications [7], Morphology, anatomy, palynology and nutlets micromorphology of Salvia macrochlamys in Turkey [8]. This research tries to present identification key of species based on micromorphology of mericarp.

\section{Materials and Methods}

Mericarp features of 10 Salvia species from NE Iran kept in FUMH including: S. ceratophylla L., S. chorassanica

\footnotetext{
"Corresponding author.
}

Bunge, S. aethiopis L. S. atropatana Bunge, S. leriifolia Bent, S. sclarea L., S. macrosiphon Boiss, S. chloroleuca Rech. f. \& Aellen, S. virgata Jacq., S. nemorosa L. were examined. The localities of studied Salvia species were presented in Table 1. The nutlets were coated with sputter and studied by SEM XL 30. The features such as the size, color, shape, polar axis length/equatorial axis length and ornamentation were evaluated in magnification 25 and 500 .

\section{Results}

\subsection{Identification Key of Salvia Species Based on Nutlet Features}

1a-Reticulate. S. ceratophylla

$1 \mathrm{~b}-$ non reticulate......................................

2a-stripped...........................................

2b—stripped with prominence (swollen)................

3a-simple stripped.................................

3b-undulated stripped.................................6

$4 a-$-stripped with deep and coarse grooves.....S. sclarea

$4 \mathrm{~b}-$ stripped with fine grooves.......................... 5

$5 a-$ minute grooves........................S. macrosiphon

$5 \mathrm{~b}$ - shallow, regular and fine grooves.....S. chloroleuca

$6 a$-fine and distant grooves................... nemorosa

$6 \mathrm{~b}$-coarse-fine and close grooves...............S. virgata

7a-hexagonal prominence............................. 8

7b-circular prominence.............................9

$8 \mathrm{a}$-regular hexagonal prominence.............. aethiopis 
Table 1. The localities of studied Salvia species.

\begin{tabular}{|c|c|}
\hline Species & Locality \\
\hline S. atropatana Bunge & $\begin{array}{l}\text { West north of Quchan, Galil, } 2100 \text { m, Zangouei, 25824, FUMH; west north of Boujnord, Misi nou mount, } 1800 \\
\text { m, Joharchi \& Zangouei, 20819); west north of Boujnord, Gouinik mount, } 1435 \text { m, Joharchi \& Zangouie, 40134, } \\
\text { (FUMH). }\end{array}$ \\
\hline S. chorassanica Bunge & $\begin{array}{l}\text { Between Quchan-Drgaz, northern slope of Allahoakbar mount, } 1650 \text { m, Joharchi \& Zangouie, 16868, (FUMH); } \\
\text { North of Masshad, Kalat road, southern mounts of Sandough shekan pass, } 1550 \text { m, Jopharchi \& Zangouie, 16825, } \\
\text { (FUMH). }\end{array}$ \\
\hline S. sclarea L. & $\begin{array}{l}\text { Boujnord, Badranlou pass, } 20 \text { km Boujnord, } 1450 \text { m, Jopharchi \& Zangouie, 10625, (FUMH); West of Boujnord, } \\
\text { base of road, } 1485 \text { m, Jopharchi \& Zangouie, 40436, (FUMH). }\end{array}$ \\
\hline S. aethiopis L. & $\begin{array}{l}\text { west South of Boujnord, Rein, } 1700 \text { m, Jopharchi \& Zangouie, 37949, (FUMH); west north of Boujnord, between } \\
\text { Koinic and Baghlogh, Jopharchi, 33706, (FUMH); West of Boujnord, after GharehNowDeh, } 1485 \text { m, } \\
\text { Jopharchi\&Zangouie, 40442, (FUMH). }\end{array}$ \\
\hline S. ceratophylla L. & $\begin{array}{l}10 \text { km Torbat Heidarieh to Khaf, } 1000 \text { m, Jopharchi, 13720, (FUMH); Sarakhsroad, Chahak hills, Jopharchi \& } \\
\text { Zangouie, 14526, (FUMH). }\end{array}$ \\
\hline S. leriifolia Bent & $\begin{array}{l}\text { West of Sabzevar, mountains of east Sarough, } 1650 \text { m, Joharchi \& Zangouie, 42420, (FUMH)Gonabad, Ab Sanou } \\
\text { mount, Joharchi \& Zangouie, 12835, (FUMH). }\end{array}$ \\
\hline S. macrosiphon Boiss & $\begin{array}{l}\text { Between Srakhs- Mashhad, Bazangan, Joharchi \& Zangouie, 16756, (FUMH); West north of Ghaen, Dashte } \\
\text { Baiaz, } 1900 \text { m, Joharchi, 34480, (FUMH). }\end{array}$ \\
\hline S.chloroleuca Rech. f. \& Aellen & $\begin{array}{l}\text { East of Quchan, Iadak, } 1700 \text { m, Joharchi \& Zanghouie, 12890, (FUMH); North of Mashhad, Kardeh, } 1100 \text { m, } \\
\text { Joharchi \& Zanghouie, 12929, (FUMH). }\end{array}$ \\
\hline S. virgata L. & $\begin{array}{l}\text { Kalate naderi, } 1100 \text { m, Zangouie, 11198, (FUMH); Torbate Heydarieh, } 1340 \text { m, Rafeie \& Zangouie, } 23176 \text {, } \\
\text { (FUMH). }\end{array}$ \\
\hline S. nemorosa L. & $\begin{array}{l}\text { East south f Boujnord, Esfidan, 1561 m, Joharchi \& Zanghouie, 40219, (FUMH); Quchan, Oghaz kohneh, } 1800 \\
\text { m, Faghihnia \& Zangoure, 29451, (FUMH). }\end{array}$ \\
\hline
\end{tabular}

8b-irregular hexagonal prominence. S. leriifolia

9a—distant irregular circular prominence.................S. chorassanica

$9 \mathrm{~b}$-close circular prominence S. atropatana

\subsection{Description of Studied Salvia Nutlets}

\subsubsection{S. ceratophylla}

Spherical mericarp, P/E 1.26, dark brown, reticulate with square and irregular reticulations or nets, hairy, the length of reticulations were 25 - $50 \mu$ (Figures 1(a) and 2(a)).

\subsubsection{S. chorassanica}

Trigonous and prolate spheroidal mericarp, P/E 1.63, light brown, with distant irregular circular prominence, the distance between prominences were $50-70 \mu$ (Figures 1(b) and 2(b)).

\subsubsection{S. aethiopis}

Trigonous and prolate spheroidal mericarp, P/E 1.57, pale brown with regular hexagonal prominence, the distance between prominences were $20 \mu$ (Figures 1(c) and 2(c)).

\subsubsection{S. atropatana}

Spherical mericarp, P/E 1.39, black, with close, irregular circular prominences, the distance between prominences were $30 \mu$ (Figures 1(d) and 2(d)).

\subsubsection{S. leriifolia}

Spherical mericarp, P/E 1, black, with irregular hexagonal prominences, the distance between prominences were $20 \mu$ (Figures 1(e) and 2(e)).

\subsubsection{S. sclarea}

Ovoid mericarp, P/E 1.37, pale brown, stripped with regular, deep and coarse grooves, the distance between grooves were 2 - $3 \mu$ (Figures 1(f) and 2(f)).

\subsubsection{S. macrosiphon}

Spherical mericarp, P/E 1.15, dark green stripped with minute and irregular grooves, the distance between grooves were 0.5 - $1 \mu$ (Figures $\mathbf{1}(\mathbf{g})$ and $\mathbf{2 ( g )}$ ).

\subsubsection{S. chloroleuca}

Spherical mericarp, P/E 1.36, light brown, yellow, stripped with minute, irregular and shallow grooves, the distance between grooves were $1-2 \mu$ (Figures 1(h) and 2(h)).

\subsubsection{S. virgata}

Ovoid mericarp, P/E 1.28, dark brown, undulated- 

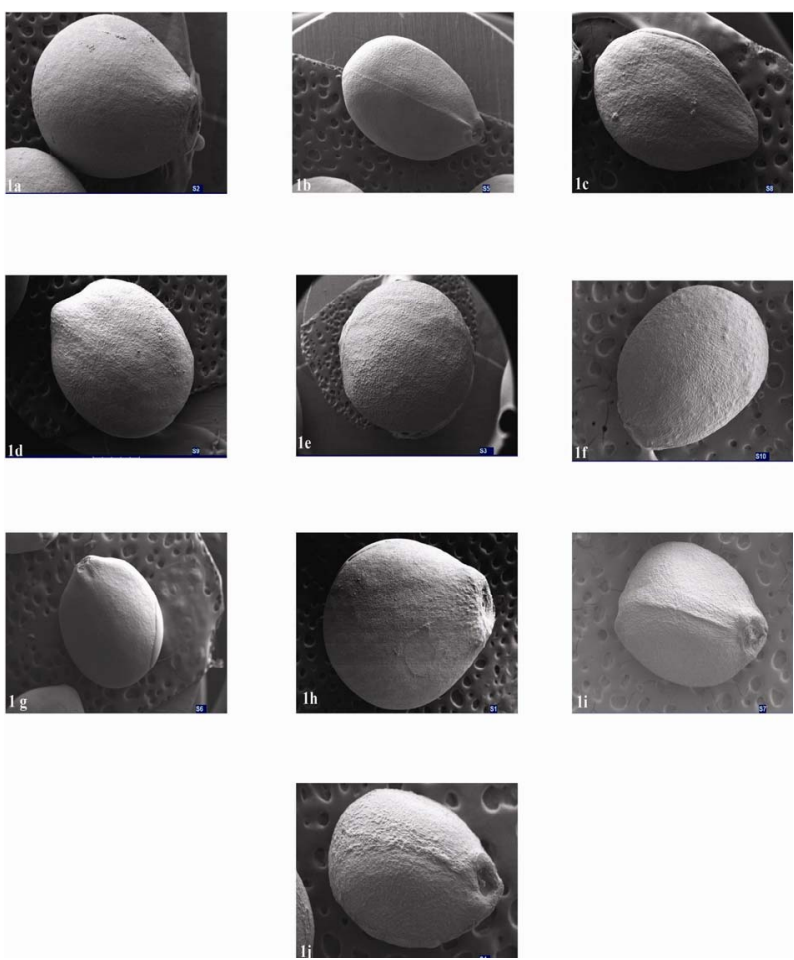

Figure 1. Electromicrographs of mericarps: (a) S. ceratophylla, (b) S. chorassanica, (c) S. aethiopis, (d) S. atropatana, (e) S. lerrifolia, f) S. sclarea, (g) $S$. macrosiphon, (h) $S$. chloroleuca, (I) S. virgata, (J) S. nemorosa.
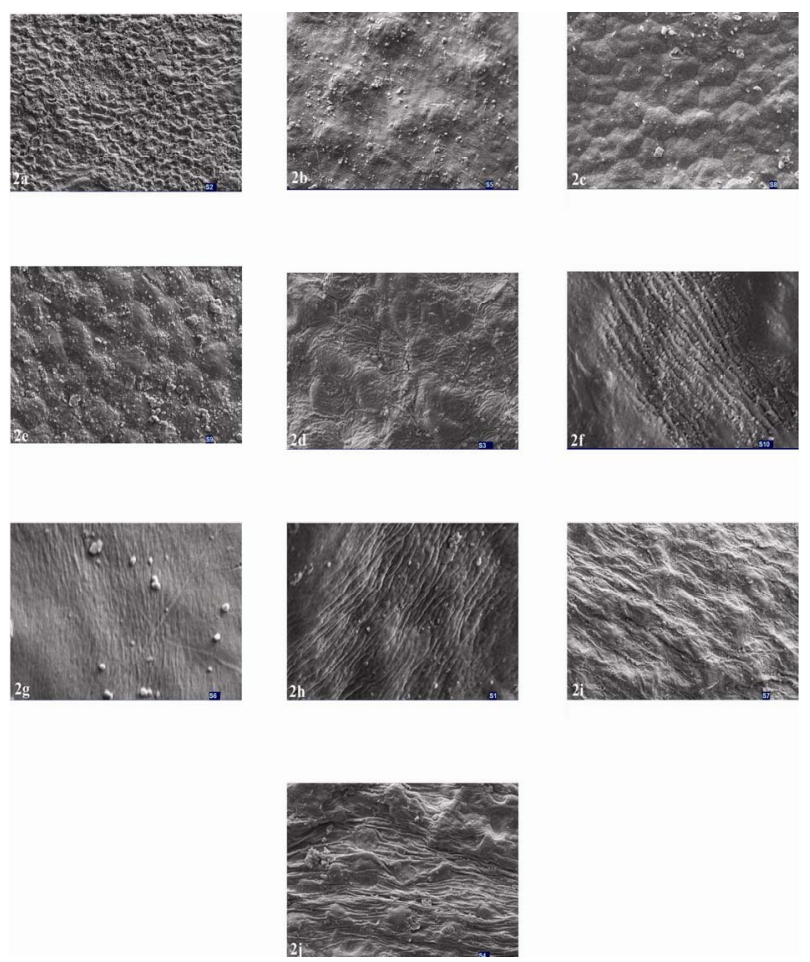

Figure 2. Electromicrographs of mericap: (a) S. ceratophylla, (b) S. chorassanica, (c) S. aethiopis, (d) S. atropatana, (e) $S$. leriifolia, f) S. sclarea, (g) S. macrosiphon, (h) S. chloroleuca, (i) S. virgata, (j) $S$. nemorosa. stripped, with coarse-fine grooves and close prominences, the distance between prominences were 15 - $20 \mu$ (Figures 1(i) and 2(i)).

\subsubsection{S. nemorosa}

Ovoid mericarp, P/E 1.38, black, undulated-stripped, with distant coarse-fine grooves and distant circular prominences, the distance between prominences were 40 - $50 \mu$ (Figures 1(f) and 2(f)).

\section{Discussions}

The results showed S. chorassanica and S. leriifolia had the maximum and minimum nutlet size respectively. The nutlets were divided into three groups based on their shape:

1) Trigonous and prolate spheroidal like S. chorassanica, and S. aethiopis;

2) Spherical such as $S$. chloroleuca, S. atropatana, $S$. leriifolia, S. macrosiphon and S. ceratophylla;

3) Ovoid like S. sclarea, S. nemorosa and S. virgata. Also four groups were recognized based on mericarp ornamentation:

a) Reticulate with shallow, fine and irregular reticulations in S. ceratophylla;

b) With regular or irregular hexagonal and circular prominences like S. chorassanica, S. aethiopis, S. atropatana and S. leriifolia;

c) Stripped with regular and irregular, deep or shallow grooves such as $S$. sclarea, $S$. microsiphon and $S$. chloroleuca;

d) Prominent stripped in S. virgata and S. nemorosa.

Ozkan et al., reported the nulets are placed in three groups based on the shape and ornamentation (spherical, trigonous and prolate spheroidal) and (foveate, reticulate and verrucate) respectively [1]. Between 12 studied Salvia nutlets in their study, S. ceratophylla, S. aethiopis and $S$. virgata were common with the present research. Ozkan explained $S$. aethiopis and S. virgata nutlets ornamentation are foveate and reticulate while in present research, it was preferred to name, surface with hexagonal prominences and undulated stripped respectively. Also, Kahraman et al. pointed the size, shape and ornamentation of S. ballsiana, S. macrochlamys and S. hedgeana are diagnostic $[7,8]$. In conclusion, the shape, color and ornamentation of Salvia mericarps varied among the species and those are taxonomical characters help to identify species.

\section{REFERENCES}

[1] C. Ozdemir and G. Senel, "The Morphological, Anatomical and Karyological Properties of Salvia sclarea L.,” Turkish Journal of Botany, Vol. 23, No. 1, 1999, pp. 7-18. 
[2] I. C. Hedge, “Labiatae,” In: K. H. Rechinger, Ed., Flora Iranica, Academische Druck-U. Verlagsantalt, Graze, Vol. 150, 1982, pp. 403-476.

[3] I. C. Hedge, “Salvia L. ,” In: P. H. Davis, Ed., Flora of Turkey and the East Aegean Islands, Vol. 10, Edinburgh University Press, Edinburgh, 1982, pp. 400-402.

[4] I. C. Hedge, “Labiatae,” In: S. I. Ali, Ed., Flora of Pakistan, Royal Botanic Garden, Edinburgh, 1990, pp. 193217.

[5] S. Haqe, "Chromosome Numbers in the Genus Salvia L.," Proceedings of the Indian Academy of Science, Vol. 47, 1981, pp. 419-426.

[6] M. Özkan, K. Aktab, C. Özdemir and G. Gurin, "Nutlet Morphology and Its Taxonomic Utility in Salvia (La- miaceae: Mentheae) from Turkey,” Acta Botanica Croatica, Vol. 68, No. 1, 2009, pp. 105-115.

[7] A. Kahraman, M. Dogan, F. Celep, M. Koyucu and G. Akaydin, "Morphology, Anatomy, Palynology and Nutlet Micromorphology of the Rediscovered Turkish Endemic Salvia ballsiana (Lamiaceae) and Their Taxonomic Implications," Nordic Journal of Botany, Vol. 28, No. 1, 2010, pp. 91-99. doi:10.1111/j.1756-1051.2009.00384.x

[8] A. Kahraman, F. Celep and M. Dogan, "Morphology, Anatomy, Palynology and Nutlet Micromorphology of Salvia macrochlamys (Labiatae) in Turkey,” Biologia, Vol. 65, No. 2, 2010, pp. 219-227. doi:10.2478/s11756-010-0013-y 